\title{
Variability of air mass occurrence in southern Poland (1951-2010)
}

\author{
Pawel Kotas • Robert Twardosz $\cdot$ Zenon Nieckarz
}

Received: 3 February 2012 / Accepted: 18 February 2013 / Published online: 12 March 2013

(C) The Author(s) 2013. This article is published with open access at Springerlink.com

\begin{abstract}
The paper discusses the frequency, persistence and succession sequence of six types of air mass during the period 1951-2010. The study, which relied on a calendar of air masses in southern Poland published by $\mathrm{T}$. Niedźwiedź, concludes that there is no simple relationship between the persistence and the frequency of specific air masses in the region. The study found that there was a great variety in the persistence of specific types of air mass and that persistence depended more on the direction of air mass advection than on their frequency of occurrence. The study also failed to identify any strict overall rule of succession, as any air mass could follow after any other, but certain finergrained patterns emerged. In winter and summer, arctic air (A) never followed directly after tropical air (T) or vice versa. Also, the most frequent succession sequence identified was from Polar maritime fresh air (mPf) to Polar maritime old and it accounted for the vast majority of successions from $\mathrm{mPf}$ into any other air mass (63\% annually and $76 \%$ in summer).
\end{abstract}

\section{Introduction}

The types of air mass present over an area significantly influence the local weather. This influence goes beyond

\author{
P. Kotas $\cdot$ R. Twardosz $(\bowtie)$ \\ Department of Climatology, Jagiellonian University, \\ ul. Gronostajowa 7, \\ 30-387 Kraków, Poland \\ e-mail: r.twardosz@uj.edu.pl \\ P. Kotas \\ e-mail: pawel.kotas@uj.edu.pl \\ Z. Nieckarz \\ Experimental Computer Physics Department, Institute of Physics, \\ Jagiellonian University, ul. Reymonta 4, \\ 30-059 Kraków, Poland \\ e-mail: zenon.nieckarz@uj.edu.pl
}

specific values of weather elements and also covers their timing (Niedźwiedź 1981; Twardosz 2005; Twardosz et al. 2011a, b), especially in the case of dangerous atmospheric phenomena (Twardosz 2010). The study of air mass variability has the potential, therefore, to contribute to both applied meteorology and to a better understanding of the causes behind contemporary climate variation, especially the observed growth in air temperature (Kalkstein et al. 1998; Twardosz and Kossowska-Cezak 2012). Nevertheless, climatologists rarely take up this topic because, as was aptly pointed out by Ustrnul (2007), there is a severe shortage of calendars of air mass types.

What research is available is mainly about the frequency of occurrence of air masses. Relevant studies pertaining to the territory of Poland include those by Rafałowski et al. (1955), Bołaszewska and Reutt (1962), Warakomski (1969), and Więcław (2004), while works published by Buchert (2006) and Niedźwiedź $(2000,2003)$ went down to the scale of a region. A notable study by Kaszewski (1977) identifies a relationship between arctic and tropical air advection, on the one hand, and synoptic situations in central-eastern Poland on the other. The seasonality of air mass frequency was also studied in other areas, especially in the USA (Schwartz 1995; Kalkstein et al. 1996, 1998). These studies also detail methods for the identification of air mass types.

Persistence is a characteristic of air mass variability that is both important, especially for forecasting (OsuchowskaKlein 1975), and rarely researched. Studies into this characteristic were published, among others, by Warakomski (1969), Więcław (2004), and recently by Kotas (2011). Studies on persistence are, however, available for circulation types (e.g. Kyselý and Domonkos 2006)

In this study, the authors focused on the seasonal and annual variability of six air mass types in southern Poland during the 60 years spanning 1951-2010. Three characteristics were taken into account: frequency, persistence and succession sequence. 


\section{Data and methods}

The study relies on a calendar of air masses of southern Poland during the period 1951-2010 published by Niedźwiedź (2011). Air masses identified by Niedźwiedź are based on a classification widely adopted in meteorological services (American Meteorological Society 2000) which involves source regions (known as a "geographical classification") and thermal and moisture properties (c - continental, $\mathrm{m}$ - maritime, $\mathrm{w}$ - warm) based on a classification by Bergeron (1928). Niedźwiedź identified six air masses:

- Arctic-A

- Polar maritime (fresh) - $\mathrm{mPf}$

- Polar maritime old (transformed) - mPo

- Polar maritime warm-mPw

- Polar continental-cP

- Tropical-T

Niedźwiedź classified days with more than one air mass as days with various air masses (vAm). His study area was defined as: $49-51^{\circ} \mathrm{N}$ and $18-24^{\circ} \mathrm{E}$ (Fig. 1).

Using his calendar, the authors identified the average frequency and persistence of air masses in separate seasons and in the whole year and their confidence intervals. Strings of days with a given air mass interrupted by a single day with a different air mass were still counted as one. Strings that straddled across a seasonal divide were included in the season where a larger portion of the days fell or, where these numbers were equal, the string was included in the earlier season. The study also investigated the variability of frequency and of persistence through the period.

For each air mass type, the study identified the numbers of strings of different persistence, their frequencies and the proportion of the total days in strings of a given length in the overall total number of days with that air mass in the period.

The frequency of succession sequences was also identified, i.e. the occurrence after a given air mass of another air mass. The research topic of succession deals with qualitative data, such as air masses. In this study, succession was approached in two ways: (1) by investigating the frequency of the total variability (all instances of succession from one air mass to another representing $100 \%$ ) and (2) by investigating the frequency of succession from a given air mass to another given air mass (where the frequency of all instances of succession from the former air mass represent $100 \%$ ).

\section{Frequency}

Air masses in southern Poland feature a whole range of thermal and humidity characteristics. During the 60-year

Fig. 1 Location of study area

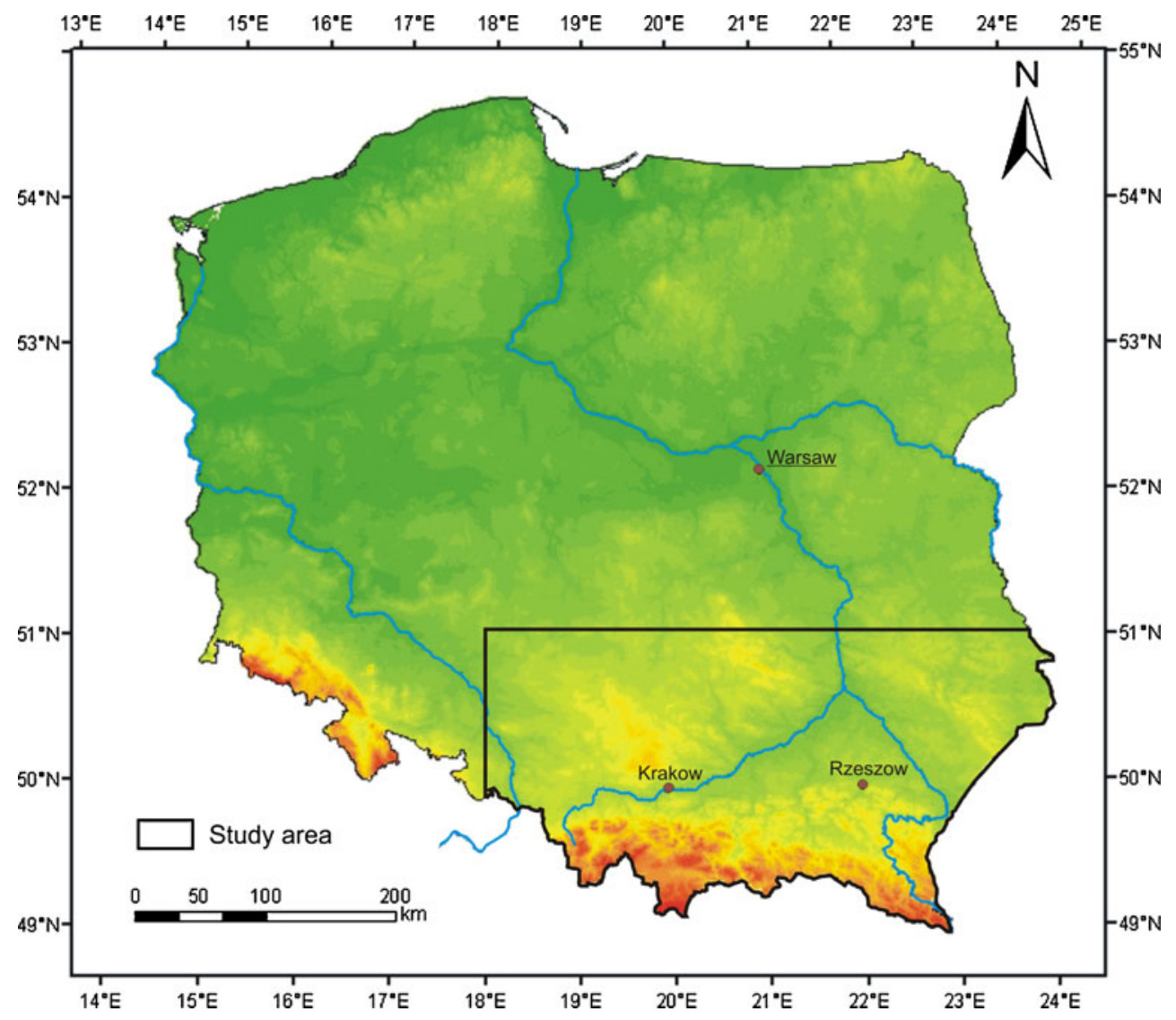


Table 1 Frequency (in percent) of air masses over southern Poland and its $95 \%$ confidence interval (1951-2010)

\begin{tabular}{lrrrrr}
\hline Air masses & \multicolumn{1}{c}{ Spring } & Summer & Autumn & Winter & \multicolumn{1}{c}{ Year } \\
\hline Arctic-A & $11.6 \pm 1.8$ & $3.1 \pm 1.0$ & $8.6 \pm 1.4$ & $8.9 \pm 1.6$ & $8.0 \pm 0.8$ \\
Polar maritime (fresh)—mPf & $13.6 \pm 1.6$ & $25.6 \pm 2.2$ & $16.6 \pm 1.8$ & $14.0 \pm 1.6$ & $17.5 \pm 1.2$ \\
Polar maritime old (transformed)—mPo & $31.1 \pm 3.0$ & $35.4 \pm 2.4$ & $31.4 \pm 2.4$ & $32.9 \pm 2.4$ & $32.7 \pm 1.8$ \\
Polar maritime warm—mPw & $6.6 \pm 1.2$ & $3.7 \pm 1.0$ & $10.2 \pm 1.6$ & $9.3 \pm 1.6$ & $7.4 \pm 0.8$ \\
Polar continental—cP & $23.5 \pm 2.6$ & $18.6 \pm 2.6$ & $20.1 \pm 2.8$ & $23.6 \pm 3.4$ & $21.4 \pm 1.6$ \\
Tropical-T & $3.7 \pm 1.0$ & $4.3 \pm 1.2$ & $3.3 \pm 1.0$ & $1.0 \pm 0.6$ & $3.1 \pm 0.6$ \\
Various air masses—vAm & $10.0 \pm 2.0$ & $9.3 \pm 1.8$ & $9.8 \pm 1.8$ & $10.5 \pm 2.0$ & $9.8 \pm 1.8$ \\
\hline
\end{tabular}

study period, the most frequent air mass was the Polar maritime old (transformed) air which accounted for approximately one third of all days, including $35 \%$ in summer and $31 \%$ in spring and autumn (Table 1). This is compatible with an earlier study by Bołaszewska and Reutt (1962), who concluded that this air mass type was the most frequent across Poland. Polar continental air was the second most frequent at $24 \%$ in winter and spring and $19 \%$ in summer. Summer was also the season when $\mathrm{mPf}$ increased in frequency to $26 \%$. Other air masses were less frequent, especially the ones originating outside the moderate latitudes, and follow seasonal patterns. Polar maritime warm air is nearly 2.5 times more frequent in autumn $(10 \%)$ than in summer (4\%); Arctic air peaks in frequency in spring $(12 \%)$ and reaches its low in summer $(3 \%)$; tropical air is at its most frequent in summer $(4 \%)$ and at the least frequent in winter $(1 \%)$. Finally, there are about $10 \%$ of days with air mass change in all seasons.

No statistically significant seasonal variability was found in the most frequent air masses, i.e. $\mathrm{mPo}$ and $\mathrm{cP}$, as they are typical of the climate zone of the study area with its consistent prevalence of zonal circulation. The remaining four air masses display clear seasonalities. There is also a great deal of year-to-year variability of the same air masses. For example, arctic air may not occur in the spring of 1 year but may persist for $30 \%$ of days in the same season of the following year (Table 2).

\section{Persistence}

\subsection{Average persistence}

In southern Poland air masses persist in strings of 2.2 consecutive days on average. There is a good deal of difference between each type, however, such as 1.6 days for $\mathrm{mPw}$ in summer and 4.3 days for $\mathrm{cP}$ in winter (Table 3 ). The most frequent air mass of all, $\mathrm{mPo}$, maintained a consistent average persistence in all seasons at 2.6 days. A much shorter average persistence was calculated for $\mathrm{mPf}$ and $\mathrm{mPw}$ air at approximately 1 day each. In summer, the two types differed significantly at $2.2 \pm 0.1$ day for $\mathrm{mPf}$ and $1.6 \pm 0.2$ day for $\mathrm{mPw}$. In the remaining seasons, any differences between these types was insignificant at $\alpha=0.05$. The relatively short persistence of $\mathrm{mPf}$ and $\mathrm{mPw}$ air masses was a result of the rapid movement of depressions across Poland accompanied by extensive systems of fronts and a subsequent transformation of these masses into mPo. This type of transformation is the quickest in winter and in spring, when the temperature differential between the Atlantic Ocean and land in Europe is at its greatest. At that time, its average persistence stands at 1.7 days. In summer, this transformation process is much slower and the persistence extends to 2.2 days on average.

Among the six types of air mass, $\mathrm{cP}$ air stands out with its longest average persistence over the whole year and no

Table 2 Range of frequency variability (a) minimum and (b) maximum (in percent) of air masses in southern Poland (1951-2010) (number of extreme occurrences in brackets)

\begin{tabular}{|c|c|c|c|c|c|c|c|c|c|c|}
\hline \multirow[t]{2}{*}{ Air masses } & \multicolumn{2}{|l|}{ Spring } & \multicolumn{2}{|l|}{ Summer } & \multicolumn{2}{|l|}{ Autumn } & \multicolumn{2}{|l|}{ Winter } & \multicolumn{2}{|l|}{ Year } \\
\hline & $\mathrm{a}$ & $\mathrm{b}$ & $\mathrm{a}$ & $\mathrm{b}$ & $\mathrm{a}$ & $\mathrm{b}$ & $\mathrm{a}$ & $\mathrm{b}$ & $\mathrm{a}$ & $\mathrm{b}$ \\
\hline A & $0.0(1)$ & 30.4 (1) & $0.0(20)$ & $14.1(1)$ & $0.0(1)$ & $24.2(1)$ & $0.0(2)$ & $22.0(1)$ & $2.5(1)$ & $17.0(1)$ \\
\hline $\mathrm{mPf}$ & $3.3(1)$ & $32.6(1)$ & $8.7(1)$ & $55.4(1)$ & $4.4(1)$ & $33.0(2)$ & $1.1(1)$ & $26.7(1)$ & 10.7 (3) & 29.0 (1) \\
\hline $\mathrm{mPo}$ & $13.0(1)$ & 70.7 (1) & 20.7 (1) & $63.0(1)$ & $13.2(1)$ & $53.8(2)$ & 14.4 (1) & $51.1(1)$ & 19.7 (1) & $53.7(1)$ \\
\hline $\mathrm{mPw}$ & $0.0(2)$ & 20.7 (1) & $0.0(11)$ & $16.3(1)$ & $1.1(1)$ & 30.8 (1) & $0.0(3)$ & $26.7(1)$ & $0.8(1)$ & $14.8(1)$ \\
\hline $\mathrm{cP}$ & $2.2(1)$ & $46.7(1)$ & $0.0(1)$ & $44.6(1)$ & $2.2(2)$ & 48.4 (1) & $1.1(1)$ & $57.8(1)$ & $8.8(1)$ & 38.9 (1) \\
\hline $\mathrm{T}$ & $0.0(20)$ & $15.2(2)$ & $0.0(17)$ & $19.6(1)$ & 0.0 (17) & $17.6(1)$ & $0.0(42)$ & $11.1(1)$ & $0.0(2)$ & $10.1(1)$ \\
\hline vAm & $0.0(6)$ & $26.1(1)$ & $0.0(6)$ & $22.8(1)$ & $0.0(8)$ & $25.3(3)$ & $0.0(6)$ & $31.1(1)$ & $0.0(3)$ & $24.4(1)$ \\
\hline
\end{tabular}


Table 3 The average persistence of air masses (in days) and their $95 \%$ confidence intervals $(1951-2010)$

\begin{tabular}{llllll}
\hline Air masses & Spring & Summer & Autumn & Winter & Year \\
\hline $\mathrm{A}$ & $2.50 \pm 0.22$ & $1.94 \pm 0.26$ & $2.29 \pm 0.20$ & $2.12 \pm 0.20$ & $2.27 \pm 0.12$ \\
$\mathrm{mPf}$ & $1.73 \pm 0.10$ & $2.17 \pm 0.14$ & $1.91 \pm 0.14$ & $1.67 \pm 0.10$ & $1.90 \pm 0.06$ \\
$\mathrm{mPo}$ & $2.52 \pm 0.16$ & $2.51 \pm 0.16$ & $2.63 \pm 0.18$ & $2.64 \pm 0.18$ & $2.57 \pm 0.08$ \\
$\mathrm{mPw}$ & $1.66 \pm 0.14$ & $1.56 \pm 0.18$ & $2.01 \pm 0.20$ & $1.93 \pm 0.16$ & $1.83 \pm 0.08$ \\
$\mathrm{cP}$ & $3.83 \pm 0.36$ & $3.32 \pm 0.32$ & $3.95 \pm 0.46$ & $4.25 \pm 0.44$ & $3.83 \pm 0.20$ \\
$\mathrm{~T}$ & $2.00 \pm 0.30$ & $1.86 \pm 0.20$ & $1.90 \pm 0.26$ & $1.56 \pm 0.30$ & $1.88 \pm 0.14$ \\
$\mathrm{vAm}$ & $1.29 \pm 0.06$ & $1.26 \pm 0.06$ & $1.22 \pm 0.06$ & $1.33 \pm 0.06$ & $1.27 \pm 0.04$ \\
Avg. & $2.30 \pm 0.08$ & $2.20 \pm 0.08$ & $2.30 \pm 0.08$ & $2.30 \pm 0.08$ & $2.27 \pm 0.04$ \\
\hline
\end{tabular}

significant seasonality $(\alpha=0.05)$. Warakomski (1969) and Wiectaw (2004) found cP to be the most persistent in the whole of Poland, which must be attributed to the very great stability of the eastern circulation from where this type of air mass comes (Osuchowska-Klein 1975).

Two air masses that arrive in southern Poland from outside moderate latitudes, i.e. T and A, stand out with their longest springtime persistence at 2 and 2.5 days, respectively. It is their effect that is behind the typically high weather variability in springtime, which ranges from frosty spells to heat waves, as meridional circulation increases its share at the cost of longitudinal circulation (Niedźwiedź et al. 2009). A-type air masses arrive in Poland in connection with high pressure systems, which tend to be more stable. Finally, air

Table 4 Number of strings of days with individual air masses (NS), frequency (in percent) of strings (FS), and the proportion (in percent) of each string length in the total number of days with that air mass type (FD) (1951-2010)

\begin{tabular}{|c|c|c|c|c|c|c|c|c|c|c|c|c|c|c|c|}
\hline \multirow{2}{*}{$\begin{array}{l}\text { Air } \\
\text { masses }\end{array}$} & & \multicolumn{13}{|c|}{ Strings of days } & \multirow[b]{2}{*}{$\Sigma$} \\
\hline & & 1 & 2 & 3 & 4 & 5 & 6 & 7 & 8 & 9 & 10 & $11-15$ & $16-20$ & $21-30$ & \\
\hline \multirow[t]{3}{*}{ A } & NS & 301 & 233 & 118 & 63 & 32 & 15 & 10 & 4 & 2 & 1 & 2 & - & - & 781 \\
\hline & FS & 38.5 & 29.8 & 15.1 & 8.1 & 4.1 & 1.9 & 1.3 & 0.5 & 0.3 & 0.1 & 0.3 & - & - & 100 \\
\hline & FD & 17.0 & 26.3 & 19.9 & 14.2 & 9.0 & 5.1 & 3.9 & 1.8 & 1.0 & 0.6 & 1.2 & - & - & 100 \\
\hline \multirow[t]{3}{*}{$\mathrm{mPf}$} & NS & 1,118 & 496 & 233 & 101 & 61 & 20 & 15 & 3 & 4 & 4 & 6 & - & - & 2,061 \\
\hline & FS & 54.2 & 24.1 & 11.3 & 4.9 & 3.0 & 1.0 & 0.7 & 0.1 & 0.2 & 0.2 & 0.3 & - & - & 100 \\
\hline & FD & 28.5 & 25.3 & 17.8 & 10.3 & 7.8 & 3.1 & 2.7 & 0.6 & 0.9 & 1.0 & 1.9 & - & - & 100 \\
\hline \multirow[t]{3}{*}{$\mathrm{mPo}$} & NS & 1,230 & 605 & 360 & 232 & 131 & 104 & 63 & 40 & 18 & 11 & 34 & 8 & - & 2,836 \\
\hline & FS & 43.4 & 21.3 & 12.7 & 8.2 & 4.6 & 3.7 & 2.2 & 1.4 & 0.6 & 0.4 & 1.2 & 0.3 & - & 100 \\
\hline & FD & 16.9 & 16.6 & 14.8 & 12.7 & 9.0 & 8.6 & 6.0 & 4.4 & 2.2 & 1.5 & 5.5 & 1.8 & - & 100 \\
\hline \multirow[t]{3}{*}{$\mathrm{mPw}$} & NS & 510 & 217 & 101 & 33 & 19 & 16 & 4 & 2 & 2 & 2 & 1 & - & - & 907 \\
\hline & FS & 56.2 & 23.9 & 11.1 & 3.6 & 2.1 & 1.8 & 0.4 & 0.2 & 0.2 & 0.2 & 0.1 & - & - & 100 \\
\hline & FD & 30.7 & 26.1 & 18.2 & 7.9 & 5.7 & 5.8 & 1.7 & 1.0 & 1.1 & 1.2 & 0.7 & - & - & 100 \\
\hline \multirow[t]{3}{*}{$\mathrm{cP}$} & NS & 301 & 271 & 195 & 103 & 113 & 58 & 31 & 45 & 31 & 24 & 38 & 15 & 5 & 1,230 \\
\hline & FS & 24.5 & 22.0 & 15.9 & 8.4 & 9.2 & 4.7 & 2.5 & 3.7 & 2.5 & 2.0 & 3.1 & 1.2 & 0.4 & 100 \\
\hline & FD & 6.4 & 11.5 & 12.4 & 8.7 & 12.0 & 7.4 & 4.6 & 7.6 & 5.9 & 5.1 & 10.1 & 5.6 & 2.6 & 100 \\
\hline \multirow[t]{3}{*}{$\mathrm{T}$} & NS & 188 & 95 & 46 & 24 & 5 & 2 & 2 & - & - & 1 & 1 & - & - & 364 \\
\hline & FS & 51.6 & 26.1 & 12.6 & 6.6 & 1.4 & 0.5 & 0.5 & 0.0 & 0.0 & 0.3 & 0.3 & - & - & 100 \\
\hline & FD & 27.5 & 27.8 & 20.2 & 14.0 & 3.7 & 1.8 & 2.0 & - & - & 1.5 & 1.6 & - & - & 100 \\
\hline \multirow[t]{3}{*}{ vAM } & NS & 1,157 & 244 & 50 & 16 & 3 & - & - & - & - & - & - & - & - & 1,470 \\
\hline & FS & 78.7 & 16.6 & 3.4 & 1.1 & 0.2 & - & - & - & - & - & - & - & - & 100 \\
\hline & FD & 61.7 & 26.0 & 8.0 & 3.4 & 0.8 & - & - & - & - & - & - & - & - & 100 \\
\hline \multirow[t]{3}{*}{ Total } & NS & 4,805 & 2,161 & 1,103 & 572 & 364 & 215 & 125 & 94 & 57 & 43 & 82 & 23 & 5 & 9,649 \\
\hline & FS & 49.8 & 22.4 & 11.4 & 5.9 & 3.8 & 2.2 & 1.3 & 1.0 & 0.6 & 0.4 & 0.8 & 0.2 & 0.1 & 100.0 \\
\hline & FD & 21.9 & 19.7 & 15.1 & 10.4 & 8.3 & 5.9 & 4.0 & 3.4 & 2.3 & 2.0 & 4.5 & 1.8 & 0.6 & 100.0 \\
\hline
\end{tabular}

The largest values given in italics 
mass change is found to be largely limited to single days and averages 1.3 days.

Generally, there is no simple relationship between the persistence of individual types of air mass and their frequency. It is the direction of advection which plays a significant role here and eastern circulation tends to supply air masses that persist for a longer time. This is particularly true of the $\mathrm{cP}$ mass, the most frequent air mass arriving with this circulation (Niedźwiedź 1981). Northern circulation favours A-type masses and their highest frequency is in springtime.

\subsection{Strings of days with air masses}

The similarity of the average seasonal persistence between various air mass types meant that in the search for differences the study had to turn to annual patterns (Table 4). Seasonal values were only compared in terms of maximum persistences (Table 5).

The persistences ranged from single days to 30-day strings (Tables 4 and 5). Single-day persistences were a clear majority, especially in the "various air mass" category (79 \%) and the tropical air (52\%). Single days were the most frequent in all types of air mass and represented the largest proportion of days with a given air mass with the exception of $\mathrm{cP}$ air. Here too, Polar continental air occurred most frequently on single days, but the total numbers of days with that air mass in other string persistences (2, 3, 5 and 11-15 day strings) were greater than that in single day occurrences.

Overall, the greatest number of strings with a single air mass type ranged from 1 to 3 days long, which was typical of their variability in both southern Poland and in the whole country (Warakomski 1969). At the other end of the spectrum, there were long spells that sometimes even involved air masses originating from outside moderate latitudes. For example, there were two long spells of A lasting for 11 consecutive days (10-20 April 1977 and 2-11 February 2004) (Table 5). Also, $\mathrm{T}$ tended to persist for longer periods and peaked at 11 days one autumn (Table 5).

Polar continental air has the widest range of persistences with the longest string lasting for 30 days (3 October-1 November 1951) (Table 5). As a result of that particular spell of Polar continental advection, this part of Europe suffered an acute precipitation deficit, including a complete lack of precipitation at many weather stations (Cebulska and Twardosz 2010).

Long persistence of a given $\mathrm{cP}$ air mass is linked with a stagnation of high pressure systems over southern Poland,

Table 5 The maximum duration of air masses (1951-2010)

\begin{tabular}{|c|c|c|c|c|c|c|c|c|}
\hline \multirow[t]{2}{*}{ Air masses } & \multicolumn{2}{|l|}{ Spring } & \multicolumn{2}{|l|}{ Summer } & \multicolumn{2}{|l|}{ Autumn } & \multicolumn{2}{|l|}{ Winter } \\
\hline & Duration & $\begin{array}{l}\text { Data of the } \\
\text { beginning } \\
\text { and end }\end{array}$ & Duration & $\begin{array}{l}\text { Data of the } \\
\text { beginning } \\
\text { and end }\end{array}$ & Duration & $\begin{array}{l}\text { Data of the } \\
\text { beginning } \\
\text { and end }\end{array}$ & Duration & $\begin{array}{l}\text { Data of the } \\
\text { beginning } \\
\text { and end }\end{array}$ \\
\hline A & 11 & $\begin{array}{l}\text { 10-20 April } \\
1977\end{array}$ & 8 & 1-8 June 1962 & 9 & $\begin{array}{c}\text { 13-21 September } \\
1977,21-29 \\
\text { October } 1997\end{array}$ & 11 & $\begin{array}{l}\text { 9-19 February } \\
2004\end{array}$ \\
\hline $\mathrm{mPf}$ & 8 & $\begin{array}{l}\text { 21-28 May } \\
\text { 1960, } 27 \\
\text { February-6 } \\
\text { March } 1990\end{array}$ & 13 & $\begin{array}{l}\text { 13-25 August } \\
\text { 1961, 2-14 } \\
\text { July 2003, 2-14 } \\
\text { August 2006 }\end{array}$ & 11 & $\begin{array}{c}24 \text { September-4 } \\
\text { October } 1997 \text {, } \\
26 \text { October-5 } \\
\text { November } 1998\end{array}$ & 6 & $\begin{array}{c}\text { 23-28 December } \\
1954,14-19 \\
\text { January } 1984\end{array}$ \\
\hline $\mathrm{mPo}$ & 16 & $\begin{array}{l}23 \text { March-7 } \\
\text { April 1951, } \\
18 \text { April-3 } \\
\text { May } 2006\end{array}$ & 16 & 10-25 June 1989 & 16 & $\begin{array}{c}\text { 1-16 November } \\
1959,10-25 \\
\text { October } 1980\end{array}$ & 19 & $\begin{array}{l}20 \text { December } 1960- \\
7 \text { January } 1961\end{array}$ \\
\hline $\mathrm{mPw}$ & 11 & $\begin{array}{l}26 \text { February- } \\
8 \text { March } 1959\end{array}$ & 7 & $\begin{array}{l}25 \text { June-1 } \\
\text { July } 2009\end{array}$ & 10 & $\begin{array}{l}\text { 7-16 October } \\
1976,18-27 \\
\text { October } 1989\end{array}$ & 9 & $\begin{array}{l}30 \text { November- } \\
8 \text { December } 2000\end{array}$ \\
\hline $\mathrm{cP}$ & 22 & $\begin{array}{l}11 \text { March-1 } \\
\text { April } 1956\end{array}$ & 19 & $\begin{array}{r}23 \text { May-10 } \\
\text { June } 1963\end{array}$ & 30 & $\begin{array}{l}3 \text { October-1 } \\
\text { November } 1951\end{array}$ & 21 & $\begin{array}{l}12 \text { December } 1969- \\
1 \text { January } 1970\end{array}$ \\
\hline $\mathrm{T}$ & 11 & $\begin{array}{l}27 \text { April-7 } \\
\text { May } 1969\end{array}$ & 7 & $\begin{array}{l}\text { 7-13 July } \\
\text { 2006, 21-27 } \\
\text { July } 2006\end{array}$ & 10 & $\begin{array}{l}\text { 4-13 October } \\
1966\end{array}$ & 4 & $\begin{array}{c}\text { 15-18 December } \\
1964,19-22 \\
\text { February } 1966\end{array}$ \\
\hline vAm & 5 & $\begin{array}{l}\text { 21-25 March } \\
\text { 1970, 23-27 } \\
\text { March } 1992\end{array}$ & 5 & 7-11 June 2009 & 4 & $\begin{array}{l}\text { 8-11 November } \\
1979,20-23 \\
\text { October } 1986\end{array}$ & 4 & $\begin{array}{l}\text { 6-9 February } 1981 \text {, } \\
\text { 1-4 February 1983, } \\
\text { 23-26 December } \\
\text { 1983, 20-23 } \\
\text { February } 1995\end{array}$ \\
\hline
\end{tabular}


Table 6 Frequency (in percent) of overnight change of air masses during the year
The largest values given in italics

\begin{tabular}{|c|c|c|c|c|c|c|c|c|}
\hline \multirow[t]{2}{*}{ Air mass } & & \multicolumn{7}{|c|}{ Air mass on given day } \\
\hline & & A & $\mathrm{mPf}$ & $\mathrm{mPo}$ & $\mathrm{mPw}$ & $\mathrm{cP}$ & $\mathrm{T}$ & $\mathrm{vPm}$ \\
\hline \multirow[t]{7}{*}{ Air mass on following day } & $\mathrm{A}$ & 56.0 & 4.4 & 3.1 & 2.5 & 1.2 & 1.2 & 14.7 \\
\hline & $\mathrm{mPf}$ & 4.0 & 47.4 & 11.0 & 18.8 & 2.8 & 17.4 & 33.2 \\
\hline & $\mathrm{mPo}$ & 18.8 & 33.4 & 61.1 & 13.4 & 12.1 & 13.2 & 16.8 \\
\hline & $\mathrm{mPw}$ & 2.8 & 5.4 & 5.4 & 45.5 & 1.7 & 3.1 & 7.8 \\
\hline & $\mathrm{cP}$ & 14.2 & 2.5 & 10.3 & 2.1 & 73.9 & 3.7 & 3.7 \\
\hline & $\mathrm{T}$ & 0.2 & 1.4 & 1.8 & 3.8 & 1.5 & 46.8 & 2.2 \\
\hline & vAm & 4.1 & 5.6 & 7.2 & 13.8 & 6.8 & 14.8 & 21.6 \\
\hline
\end{tabular}

especially in autumn, when they are present for up to $60 \%$ of the time on average (Twardosz et al. 2011a, b). Using the circulation calendar by Niedźwiedź (1981, 2011), it was established that in October 1951 the dominant circulation was anticyclonic with air advection from the east or southeast, which brought in the cP masses.

\section{Succession}

Succession is a very important characteristic of air masses, especially from the perspective of applied meteorology. Air masses can succeed one another by replacement (as a result of the passage of a front) or through transformation, but this division is beyond the scope of this study.

In an average year of the study period, 1951-2010, air masses were replaced or transformed on 161 days, or every
2.3 days. Differences in frequency between winter (39 days) and summer (41 days) are not due to different persistences of the air masses (on average approx. 2.3 days, Table 3), but to the different persistences of the seasons. An analysis of succession starts with showing overnight changes in air masses. Each of the six air masses under consideration has shown itself to be more likely to remain the same on the following day than to be succeeded by another air mass (Table 6). For example, in $74 \%$ of all days with $\mathrm{cP}$, this air mass continued to at least the following day and only in $26 \%$ cases was it replaced. Only the category of a "day with various air masses" (vAm) showed a reversed pattern with there being just a $22 \%$ chance of remaining the same on the following day (it was also the most likely to be replaced by mPf air).

The issue of succession was considered both in the whole year and seasonally. For the whole year the total succession frequency was used (all cases of succession account for $100 \%$
Table 7 Frequency (in percent) of air mass succession during a year: (A) total frequency and (B) frequency of succession from a given air mass to another

\begin{tabular}{|c|c|c|c|c|c|c|c|c|}
\hline \multirow[t]{2}{*}{ Air mass } & & \multicolumn{7}{|c|}{ Air mass on given day } \\
\hline & & A & $\mathrm{mPf}$ & $\mathrm{mPo}$ & $\mathrm{mPw}$ & $\mathrm{cP}$ & $\mathrm{T}$ & vAm \\
\hline \multicolumn{9}{|l|}{ A } \\
\hline \multirow[t]{7}{*}{ Air mass on following day } & $\mathrm{A}$ & - & 1.8 & 2.3 & 0.4 & 0.6 & 0.1 & 2.9 \\
\hline & $\mathrm{mPf}$ & 0.7 & - & 8.3 & 3.2 & 1.4 & 1.2 & 6.5 \\
\hline & $\mathrm{mPo}$ & 3.5 & 13.5 & - & 2.3 & 5.9 & 0.9 & 3.3 \\
\hline & $\mathrm{mPw}$ & 0.5 & 2.2 & 4.1 & - & 0.8 & 0.2 & 1.5 \\
\hline & $\mathrm{cP}$ & 2.6 & 1.0 & 7.8 & 0.4 & - & 0.3 & 0.7 \\
\hline & $\mathrm{T}$ & 0.0 & 0.6 & 1.4 & 0.7 & 0.7 & - & 0.4 \\
\hline & vAm & 0.7 & 2.3 & 5.5 & 2.4 & 3.3 & 1.0 & - \\
\hline \multicolumn{9}{|l|}{ B } \\
\hline \multirow[t]{7}{*}{ Air mass on following day } & A & - & 8.4 & 7.9 & 4.6 & 4.6 & 2.2 & 18.8 \\
\hline & $\mathrm{mPf}$ & 9.1 & - & 28.3 & 34.5 & 10.7 & 32.7 & 42.4 \\
\hline & $\mathrm{mPo}$ & 42.6 & 63.4 & - & 24.6 & 46.2 & 24.7 & 21.4 \\
\hline & $\mathrm{mPw}$ & 6.4 & 10.2 & 14.0 & - & 6.7 & 5.8 & 9.9 \\
\hline & $\mathrm{cP}$ & 32.3 & 4.7 & 26.5 & 3.9 & - & 6.9 & 4.7 \\
\hline & $\mathrm{T}$ & 0.4 & 2.6 & 4.7 & 7.1 & 5.7 & - & 2.8 \\
\hline & vAm & 9.2 & 10.6 & 18.6 & 25.4 & 26.1 & 27.7 & - \\
\hline
\end{tabular}




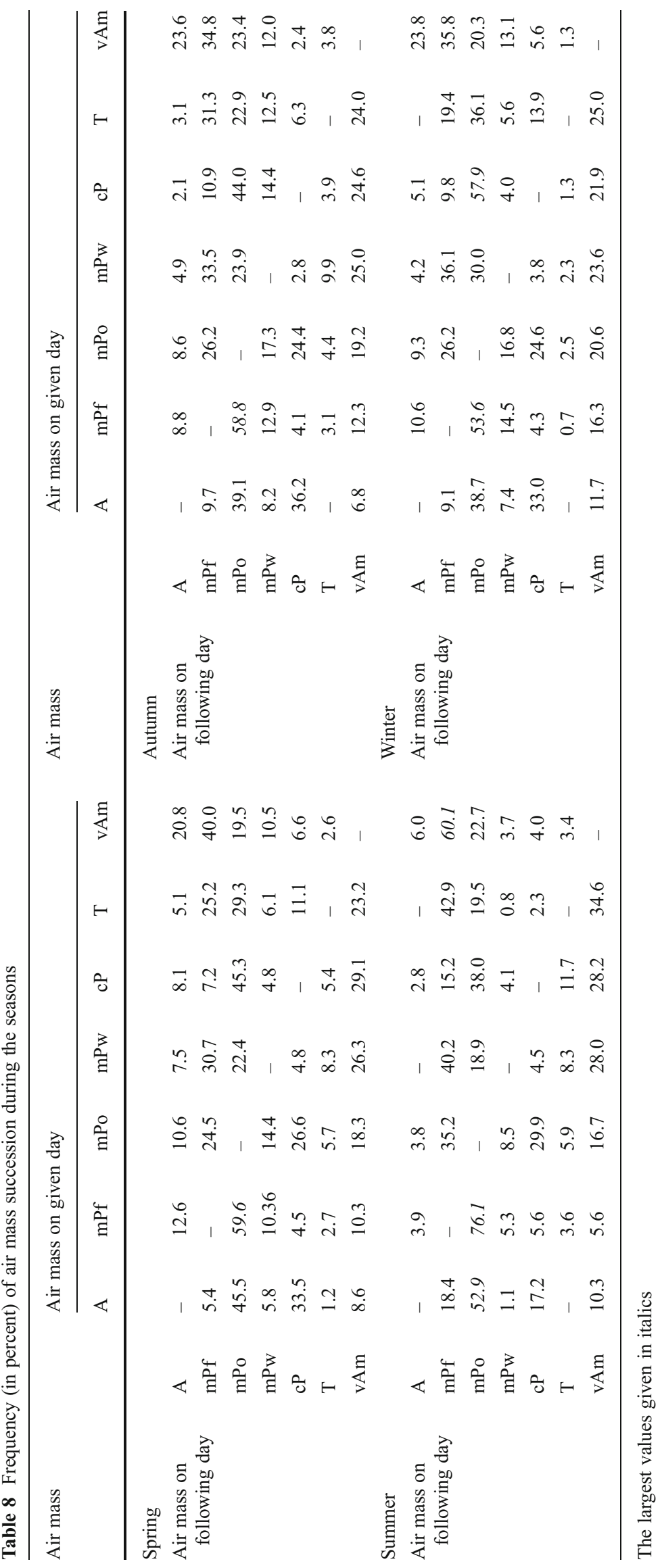


Table 7a) as well as the breakdown of succession of a given air mass $(100 \%)$ by other air masses (Table $7 b)$. The seasonal analysis considered only the latter breakdown (Table 8).

A summary of the annual succession frequency (Table 6a) shows that each air mass can be succeeded by any other. The most frequent succession is from $\mathrm{mPf}$ to $\mathrm{mPo}$ at $13.5 \%$ of all successions (1,307 succession days). It can be attributed to a natural result of the circulation processes present in the study area, involving a transformation of a fresh air mass as it arrives from the Atlantic Ocean and ventures deeper over the continent. Other frequent successions include from $\mathrm{mPo}$ to $\mathrm{mPf}$ ( $8.3 \%$ successions in a year), $\mathrm{mPo}$ to $\mathrm{cP}(7.8 \%)$ and $\mathrm{cP}$ to $\mathrm{mPo}(5.9 \%)$. Overall, there is a greater likelihood of warm air being replaced by cool air than vice versa. The least frequent are mutual successions of two air masses originating outside moderate latitudes: A to $\mathrm{T}(0.1 \%$, three cases $)$ and $\mathrm{T}$ to $\mathrm{A}(0.2 \%$, eight cases $)$, which is due to the low frequency of the air masses themselves, especially of $\mathrm{T}$. Direct successions between these two types of air can also have biometeorologically adverse effects, due to their extremely different physical properties.

From the perspective of weather forecasting, it is the frequency of successions between certain air masses that is more important. As could have been expected, there is a very high likelihood that a day with $\mathrm{mPf}$ will be followed by a day with $\mathrm{mPo}$, which accounted for $63 \%$ of mPf successions by any other air (Table 7b). This is caused by the circulation effect mentioned earlier. No other air mass has a comparable likelihood of succession by another specific air mass (more than $50 \%$ ). $\mathrm{mPo}$ is also the most frequent successor to $\mathrm{A}$ and $\mathrm{cP}$, but with less than $50 \%$ likelihood. Days with $\mathrm{mPo}, \mathrm{mPw}, \mathrm{T}$, or vAm are most likely to be followed by $\operatorname{mPf}$ (at 28, 35, 33 and $42 \%$, respectively).

The seasonal succession frequency (Table 8) displays similarities with the annual pattern described above. There is a high likelihood of a day with $\mathrm{mPo}$ after a day with $\mathrm{mPf}$, ranging from $54 \%$ in winter to $76 \%$ in summer. There is a growing frequency of a day with $\mathrm{mPo}$ after $\mathrm{A}$ in summer at $53 \%$ and after $\mathrm{cP}$ in winter at $58 \%$. All cases of the succession of $\mathrm{T}$ after $\mathrm{A}$ occurred in spring. No cases of direct mutual succession between $\mathrm{A}$ and $\mathrm{T}$, in any direction, were recorded in winter and summer.

\section{Conclusions}

The study discusses the variability of occurrence of six air mass types in southern Poland looking at their annual and seasonal frequencies, persistence, and succession patterns during the period 1951-2010.

The most frequent air masses in Poland include $\mathrm{mPo}$ at approx $33 \%$ days and $\mathrm{cP}$ at approx $21 \%$ days. These are typical air masses of the study area's climate zone and they show no significant seasonality. The other four types of air masses, on the other hand, are clearly seasonal in their frequency variabilities, especially the exotic ones (A and $\mathrm{T}$ ).

Despite considerable seasonal differences in the frequency of occurrence, the average persistence of air masses is similar for most of them at ca. 2 days. Significant differences are only visible in the $\mathrm{mPf}$, which ranges from $1.7 \pm 0.1$ days in winter and spring to $2.2 \pm 0.1$ days in summer. This means that there is no simple dependency between the persistence of each particular air mass and its frequency. There is, however, a high degree of seasonal difference between the air masses in their average persistence ranging from 1.6 days in summer (1.6 days of $\mathrm{mPw}$ and 3.2 days of $\mathrm{cP}$ ) to 2.9 in winter (1.6 of T and 4.3 of $\mathrm{cP}$ ). The greatest variability in persistence is found in $\mathrm{cP}$ air, which reaches 30 days in autumn.

The persistence of a given air mass is linked more to the direction of its advection than to the frequency of occurrence. Eastern anticyclonic circulation, known for its stability, is particularly conducive to longer persistences and this is why $\mathrm{cP}$ air tends to persist for longer. Maritime air from the west tends to be quickly transformed over the continent and does not last for as long. This transformation process is at its quickest in winter and spring and at its slowest in summer, a result of seasonal variability in cyclonic activity.

The study of succession between air masses has shown that each air mass can be replaced by any other type, although there were no recorded cases of direct mutual succession of $\mathrm{A}$ and $\mathrm{T}$ air masses in winter and summer.

There is also a very high likelihood that a day with mPf air will be followed by a day with $\mathrm{mPo}$ air. Indeed, this pattern accounts for $63 \%$ of successions of the former by any other air and in summer the proportion is $76 \%$. This pattern is a natural result of circulation processes in the temperate climate zone involving a transformation of maritime air masses over the continent. No other air mass is succeeded with such frequency by any other specific air mass type (more than $50 \%$ ). Finally, the study has confirmed an expectation that the most frequent successions would involve the air masses with the most frequent occurrence.

Acknowledgments I thank Mr. Paweł Pilch and Dr. Martin Cahn for reviewing the English language.

Open Access This article is distributed under the terms of the Creative Commons Attribution License which permits any use, distribution, and reproduction in any medium, provided the original author(s) and the source are credited.

\section{References}

American Meteorological Society (2000) Glossary of meteorology. American Meteorological Society, Boston, MA (airmass classification) 
Bergeron T (1928) Über die dredimensional verknüpfende Wetteranalyse. I. Teil (three-dimensionally combining synoptic analysis, part I). Geofysiske Publikasjoner 5:1-111

Bołaszewska J, Reutt F (1962) Częstotliwość występowania poszczególnych mas powietrza w Polsce w okresie 10 lat 19461956, Prace PIHM, 66, 16-32. [The frequency of air masses in Poland in the years from 1946 to 1956]

Buchert L (2006) Częstość występowania mas powietrznych w rejonie Poznania w latach 1965-1990, Przegląd Geofizyczny, 51 (3-4). [The frequency of air masses in the region of Poznan in the years 1965-1990]

Cebulska M, Twardosz R (2010) Zmienność czasowa najniższych miesięcznych sum opadów atmosferycznych w dorzeczu górnej Wisły (1901-2000). Przegląd Geofizyczny, 3-4, 175-188. [Temporal variability of the lowest monthly precipitation in the upper Vistula river (1901-2000)]

Kalkstein LS, Nichols MC, Barthel CD, Greene JS (1996) A new spatial synoptic clasification: application to air-mass analysis. Int J Climatol 16:983-1004

Kalkstein LS, Sheridan SC, Graybeal DY (1998) A determination of character and frequency changes in air masses using a spatial synoptic classification. Int J Climatol 18:1223-1236

Kaszewski M (1977) Warunki synoptyczne napływu powietrza arktycznego i zwrotnikowego nad środkowowschodni makroregion Polski (1961-1970). Przegląd Geofizyczny 22(30):49-59 [Synoptic conditions of the arctic and tropical air flow over central Poland (1961-1970)]

Kotas P (2011) Długotrwałość mas powietrznych w Polsce Południowej. Prace i Studia Geograficzne 47:247-253 [Long-term variability of air-mass duration in southern Poland]

Kyselý J, Domonkos P (2006) Recent increase in persistence of atmospheric circulation over Europe: comparison with long-term variations since 1881. Int J Climatol 26:461-483

Niedźwiedź T (1981) Sytuacje synoptyczne i ich wpływ na zróżnicowanie przestrzenne wybranych elementów klimatu w dorzeczu górnej Wisły, Rozprawy habilitacyjne UJ, 58, Kraków. [Synoptic situations and its influence on spatial differentiation of selected climatic elements in upper Vistula basin]

Niedźwiedź T (2000) Dynamika adwekcji mas powietrza arktycznego nad Polską południowa, Acta Universitatis Nicolai Copernici, Geografia 31. Nauki matematyczno-przyrodnicze 106:203-211

Niedźwiedź T (2003) Częstość występowania mas powietrznych w Polsce południowejw drugiej połowie XX wieku. Prace Geograficzne 188:65-74 [Frequency of air masses in southern Poland in the second half of the twentieth century]

Niedźwiedź T (2011) Kalendarz typów cyrkulacji atmosfery dla Polski południowej—zbiór komputerowy (http://klimat.wnoz.us.edu.pl/ index1024.html), Uniwersytet Śląski, Katedra Klimatologii, Sosnowiec. (Catalogue of circulation types in southern Poland)

Niedźwiedź T, Twardosz R, Walanus A (2009) Long-term variability of precipitation series in east central Europe in relation to circulation patterns. Theor Appl Climatol 98(3-4):337-350

Osuchowska-Klein B (1975) Prognostyczne aspekty cyrkulacji atmosferycznej nad Polską. Prace Instytutu Meteorologii i Gospodarki Wodnej 7:5-51 [Forecasting aspects of the atmospheric circulation over Poland]

Rafałowski S, Bołaszewska J, Reutt F (1955) Częstotliwość występowania poszczególnych mas powietrza w Polsce, Wiadomości Służby Hydrologicznej i Meteorologicznej, III, 5, 3-23. [Frequency of air masses in Poland]

Schwartz MD (1995) Detecting structural climate change: an air massbased approach in the North Central United States, 1948-1992. Ann Assoc Am Geogr 85:553-568

Twardosz R (2005) Dobowy przebieg opadów atmosferycznych w ujęciu synoptycznym i probabilistycznym na przykładzie Krakowa (1886-2002). Instytut Geografii i Gospodarki Przestrzennej UJ, Kraków. [The synoptic and probabilistic aspects of diurnal precipitation variation in Cracow (1886-2002)]

Twardosz R (2010) A synoptic analysis of the diurnal cycle of thunderstorm precipitation in Kraków (Southern Poland). Int J Climatol 30:1008-1013

Twardosz R, Kossowska-Cezak U (2012) Exceptionally hot summers in Central and Eastern Europe (1951-2010). Theor Appl Climatol. doi:10.1007/s00704-012-0757-0

Twardosz R, Łupikasza E, Niedźwiedź T (2011a) Zmienność i uwarunkowania cyrkulacyjne występowania postaci i typów opadów atmosferycznych na przykładzie Krakowa. Wydawnictwo UJ, Kraków. [Temporal variability in the form and type of precipitation in Kraków in relation to circulation patterns]

Twardosz R, Niedźwiedź T, Łupikasza E (2011b) The influence of atmospheric circulation on the type of precipitation (Kraków, southern Poland). Theor Appl Climatol 104:233-250

Ustrnul Z (2007) Warunki cyrkulacyjne, [in:] D. Matuszko (ed.), 2007, Klimat Krakowa w XX wieku,21-40, IGiGP UJ, Kraków. [Atmospheric circulation conditions]

Warakomski W (1969) Częstość występowania dni i okresów z poszczególnymi typami mas powietrza nad Polską (1951-1960). Przegląd Geofizyczny 1:67-77 [Frequency of days and periods with different types of air masses over Poland (1951-1960)]

Więcław M (2004) Masy powietrza nad Polską i ich wpływ na typy pogody, Akademia Bydgoska im. Kazimierza Wielkiego, Bydgoszcz [Air mass over Poland and their impact on the types of weather] 